Katarzyna Brendzel-Skowera ${ }^{1}$

\title{
SCOUTING W PROCESIE KOMERCJALIZACJI WIEDZY
}

\begin{abstract}
Streszczenie: Artykuł ma charakter przeglądowy a jego celem jest zaprezentowanie scoutingu wiedzy. To tylko jedno z zagadnień związanych z komercjalizacją wiedzy, a szczególnie z początkowym etapem tego procesu. Scouting to metoda identyfikacji projektów naukowych, które charakteryzują się wysokim potencjałem rynkowym. W artykule przedstawiono zakres prac scoutów oraz ich zadania i kompetencje. Wskazano również na problemy, które stanowią przyczynek do dyskusji wokół komercjalizacji wyników badań naukowych.
\end{abstract}

Słowa kluczowe: komercjalizacja wiedzy, potencjał intelektualny, scouting, transfer technologii, uczelnia.

\section{Wstęp}

Efektywne zarządzanie kapitałem intelektualnym staje się kluczową kompetencją nowoczesnych przedsiębiorstw. Konsekwencją tych zmian jest przekształcanie się współczesnych przedsiębiorstw w organizacje oparte na wiedzy, inteligentne, koncentrujące swoje działania w procesie zarządzania na zasobach niematerialnych, w których wartość dodana powstaje w oparciu o efektywne wykorzystywanie różnych form wiedzy reprezentowanej przez kompetentnych pracowników, wiedzy zgromadzonej w bazach danych czy wiedzy pozyskiwanej w drodze sieci powiązań. Dlatego uczelnie, które tworzą wiedzę stają się ważnym partnerem dla nowoczesnych przedsiębiorstw. Stwierdzenie, że „wiedza ma szczególne znaczenie wtedy, kiedy możliwe jest jej praktyczne wykorzystanie" [1] stanowi doskonałe uzasadnienie dla współpracy nauki i biznesu.

Uczelnia przestaje pełnić wyłącznie funkcje naukowe i dydaktyczne a jej misją staje się również kreowanie i stymulowanie innowacji [2]. Istnieje konieczność budowania i umacniania pomostu pomiędzy nauką a przemysłem. Służą temu różne rozwiązania organizacyjne stosowane na wyższych uczelniach, jak centra technologii, parki naukowo-technologiczne, inkubatory przedsiębiorczości czy rady biznesu. Zetknięcie podmiotów sfery nauki oraz sfery gospodarki nie przebiega jednak bez przeszkód [3] a ich współpraca nie daje oczekiwanych efektów.

Jednym z instrumentów pozwalających poprawić i zintensyfikować współpracę uczelni i przedsiębiorstw jest scouting technologiczny czy scouting wiedzy. Jego idea została przyjęta $\mathrm{z}$ sektora przedsiębiorstw i zaadaptowana na potrzeby uczelni

\footnotetext{
${ }^{1}$ Dr inż., Politechnika Częstochowska, katarzyna.brendzel-skowera@wz.pcz.pl.
} 
wyższych oraz jednostek naukowych. Niniejsze opracowanie ma charakter przeglądowy i jego celem jest przybliżenie problematyki uczelnianego scoutingu wiedzy. Jest to rozwiązanie stosowane na wielu uczelniach europejskich a pionierem w Polsce jest Uniwersytet Łódzki.

\section{Uczelniany scouting wiedzy}

Scouting technologiczny najprościej można określić jako system identyfikowania, monitorowania i oceny potencjału komercyjnego rozwiązań innowacyjnych lub wyników prac badawczych [4]. Pojęcie to wywodzi się z sektora gospodarczego. Tym mianem określa się usystematyzowane podejście przedsiębiorstwa, w ramach którego przedsiębiorstwo asygnuje część swoich zasobów ludzkich lub też zatrudnia konsultantów zewnętrznych w celu zbierania informacji z zakresu nauki i techniki. Podejście to ułatwia pozyskiwanie technologii [5].

Scouting technologiczny może być ukierunkowany na określone technologie lub też nieukierunkowany, identyfikujący luki technologiczne lub rynki dotąd przez dane podmiot nie obsługiwane. Istotnym elementem scoutingu technologicznego jest korzystanie $\mathrm{z}$ formalnych, ale i nieformalnych źródeł informacji, włączając w to osobiste kontakty scoutów. „Scouting” oznacza tym samym niejako „wyjście w teren", poza granice organizacji i formalnych kontaktów w celu rozwoju technologii i jej biznesowych zastosowań [6].

Od lat dziewięćdziesiątych XX wieku scouting technologiczny, jako narzędzie sprawdzone przez przedsiębiorstwa, zaczęły wykorzystywać uczelnie wyższe i jednostki naukowe. Jego zalety zauważyło szereg uczelni wyższych w Europie, takich jak: Uniwersytet w Oxfordzie, Politechnika w Turynie, Politechnika w Eindhoven, Biomedicum Helsinki i jako jeden z pierwszych w Polsce - Uniwersytet Łódzki. Poprzez wprowadzenie w struktury uczelni scoutów uczelnie te uzyskują silne wsparcie, już nie tylko z jednostek takich, jak: centra transferu technologii czy inne działające w ramach uczelni [4].

Uczelniany scouting wiedzy polega na skoncentrowaniu wysiłku zespołu scoutów na pozyskaniu z jednej strony informacji o stanie wiedzy w ramach uczelni [7] a z drugiej informacji o zapotrzebowaniu rynku na nowe rozwiązania. Kluczowym jest poznanie potencjału wiedzy uczelni. Jest to wyzwanie wymagające systematycznej pracy realizowanej bezpośrednio $\mathrm{z}$ pracownikami badawczonaukowymi. Regularne spotkania z naukowcami dają możliwość uzyskania użytecznej informacji o działalności danego naukowca lub zespołu naukowego. Zadaniem scouta jest poznać m.in. zakres prac badawczo-naukowych i obszary kompetencji pracowników uczelni oraz zidentyfikować możliwości komercjalizacji wiedzy i możliwe obszary współpracy z otoczeniem gospodarczym uczelni [7]. Błędne jest sprowadzanie scoutingu do aktywnej postawy części pracowników naukowych, którzy 
wykorzystując często kontakty nieformalne podejmują współpracę z przedsiębiorcami. To jest przykład na istnienie postaw przedsiębiorczych w środowisku akademickim, których celem jest wdrażanie wyników prac naukowych do przemysłu. Są to jednak działania o ograniczonym - indywidualnym zakresie, wymagające bardzo aktywnej postawy naukowca. Zadaniem scoutów jest identyfikowanie prac naukowych i ocena ich potencjału komercyjnego w skali całej uczelni. Należy podkreślić, że w warunkach tak dużych organizacji jak uczelnia wymagane jest tworzenie zespołu scoutów. Uzasadnione jest to liczbą zatrudnionych pracowników naukowych oraz dodatkową możliwością przepływu wiedzy, wzmocnienia procesu uczenia się i stymulowania kreatywności. Sieć scoutów, by przynieść oczekiwane efekty wymaga współpracy z pozostałymi jednostkami organizacyjnymi uczelni powołanymi dla komercjalizacji wiedzy.

\subsection{Scouting - współpraca w ramach uczelni}

Do grupy jednostek uczelnianych działających na styku sfery nauki i biznesu zaliczamy przede wszystkim centra transferu technologii (CTT), które funkcjonują na większości polskich uczelni. Ich zakres działań jest bardzo szeroki i obok komercjalizacji wiedzy obejmuje również szkolenia i usługi doradcze dla naukowców. Często CTT są wspomagane poprzez [8]: przedstawiciela dziekana ds. kontaktów $\mathrm{z}$ biznesem/otoczeniem, przedstawiciela rektora ds. kontaktów $\mathrm{z}$ biznesem/ otoczeniem, brokera innowacji, inkubator przedsiębiorczości/technologiczny i uczelniane bazy danych (Tabela 1).

Tabela 1. Znaczenie uczelnianych jednostek $w$ procesie komercjalizacji wiedzy

\begin{tabular}{|c|c|c|c|c|}
\hline & $\begin{array}{c}\text { Poszukiwanie } \\
\text { nowej wiedzy }\end{array}$ & $\begin{array}{c}\text { Ocena, } \\
\text { selekcja }\end{array}$ & $\begin{array}{c}\text { Transfer } \\
\text { wiedzy }\end{array}$ & $\begin{array}{c}\text { Po } \\
\text { transferze }\end{array}$ \\
\hline Przedstawiciel dziekana & + & + & - & + \\
\hline Przedstawiciel rektora & - & - & - & - \\
\hline Broker innowacji & + & ++ & +++ & - \\
\hline Uczelniane bazy danych & + & - & - & - \\
\hline CTT & + & +++ & +++ & + \\
\hline Inkubator & $-/+$ & $-/+$ & + & +++ \\
\hline Scouting wiedzy & +++ & ++ & + & - \\
\hline
\end{tabular}

- brak zastosowania, + niewielka skuteczność, ++ umiarkowana skuteczność, +++ wysoka skuteczność Źródło: Głodek P., Wieśniewska M. "Uczelniany scouting wiedzy, jako element systemu komercjalizacji wiedzy w ramach uczelni wyższej”, Ekonomiczne Problemy Ustug. Zeszyty Naukowe Uniwersytetu Szczecińskiego, No 121, pp. 279-292, 2015 
Każda $\mathrm{z}$ wymienionych jednostek ma swój obszar działalności. Etapem procesu ukierunkowanego na budowanie oferty uczelni, w którym brak skutecznego narzędzia jest „poszukiwanie wiedzy”. Sieć scoutów koncentrując się na poszukiwaniu wiedzy użytecznej praktycznie stanowi ważny instrument wypełniający swoistą lukę w procesie komercjalizacji wiedzy. W oparciu o scouting uczelniany możliwe jest więc uzupełnienie modelu zarządzania procesem komercjalizacji wiedzy. Głównymi etapami procesu z przypisanymi jednostkami są [7]:

- generowanie wiedzy - kadra naukowo-dydaktyczna uczelni,

- poszukiwanie wiedzy użytecznej - uczelniana sieć scoutów,

- ocena pozyskanej wiedzy - centrum transferu technologii, inkubator przedsiębiorczości/technologiczny,

- implementacja wiedzy - centrum transferu technologii, inkubator przedsiębiorczości/technologiczny.

\subsection{Zadania i kompetencje scoutów}

Zadania i rola uczelnianych scoutów są determinowane obszarem ich pracy. Działania podejmowane wewnątrz uczelni są związane $\mathrm{z}$ następującymi zadaniami [7wiśniewska, 281]:

- rozpoznanie potencjału badawczego uczelni - przeglądanie baz danych o publikacjach, badaniach naukowych i projektach realizowanych w uczelni; przeprowadzanie rozmów $\mathrm{z}$ pracownikami naukowymi w celu identyfikacji zakresu prowadzonych prac; udział $\mathrm{w}$ konferencjach specjalistycznych i spotkaniach biznesowych;

- gromadzenie informacji i wiedzy niezbędnej do oceny przydatności badań naukowych dla praktyki gospodarczej oraz oceny potencjału komercyjnego prowadzonych badań - udział w konferencjach specjalistycznych; przeglądanie i analiza ogólnodostępnych baz danych na temat funkcjonowania firm z zakresu dyscyplin badawczych; poszukiwanie i nawiązywanie kontaktów z potencjalnymi partnerami biznesowymi; przeprowadzenie wstępnej oceny projektów i prac naukowych pod kątem ich potencjału do komercjalizacji;

- monitoring gromadzonych informacji - uzupełnianie bazy danych o projektach i pracach badawczo-rozwojowych prowadzonych przez pracowników, cykliczna weryfikacja kompletności bazy danych i jej aktualizacja;

- budowanie relacji z pracownikami uczelni - regularne wizyty w jednostkach organizacyjnych uczelni, utrzymywanie kontaktów z pracownikami uczelni oraz przedstawicielami władz uczelni i jej jednostek organizacyjnych;

- budowanie relacji sieciowych wewnątrz zespołu scoutów - dzielenie się wiedzą z innymi scoutami na temat swoich doświadczeń, zidentyfikowanej wiedzy i jej potencjale komercyjnym, potrzeb rynku i realizacji procesu scoutingu. 
Od scouta wymagana jest również działalność w obszarze otoczenia gospodarczego uczelni. W związku z tym praca scouta musi być nakierowana na [7]:

- rozpoznanie branż, profili działalności i wykorzystywanych technologii w praktyce gospodarczej - analiza dostępnych baz danych na temat działających przedsiębiorstw w ramach adekwatnych do profilu uczelni branż, poszukiwanie potencjalnych partnerów biznesowych i nawiązywanie $\mathrm{z}$ nimi bezpośrednich kontaktów, inicjowanie współpracy pomiędzy uczelnia i otoczeniem gospodarczym;

- analizę potencjalnych zastosowań badań prowadzonych w uczelni w zidentyfikowanych przedsiębiorstwach - poszukiwanie źródeł informacji o możliwych zastosowaniach zgłoszonych przez uczelnię projektów naukowobadawczych, monitorowanie otoczenia ze względu na pojawiające się trendy w praktyce gospodarczej;

- budowę relacji z przedsiębiorstwami - regularne wizyty w przedsiębiorstwach, utrzymywanie kontaktów $\mathrm{z}$ przedstawicielami przedsiębiorstw, udział $\mathrm{W}$ konferencjach specjalistycznych, targach i innych wydarzeniach sieciujących przedsiębiorców.

W związku z powyższym scout podejmuje działania po stronie podaży i popytu na badania naukowe. By scouting przyniósł pozytywne rezultaty ważne jest traktowanie pracowników naukowych i przedsiębiorców jako klientów. Z uwagi na specyfikę kontaktów sfery nauki i biznesu konieczne jest profesjonalne, troskliwe podejście do każdego z nich. Klientami scouta w obszarze kreowania wiedzy użytecznej gospodarczo są m.in. [7]: naukowcy, zespoły badawcze, dziekani wydziałów i władze uczelni. Relacje z naukowcami są kluczowe dla powodzenia procesu komercjalizacji wiedzy a u jej podłoża powinno leżeć zaufanie. Naukowiec musi mieć zaufanie do osoby, której powierzy swoje pomysł. Scout powinien zebrać jak najwięcej informacji na temat pracy naukowej osoby, z którą zamierza się spotkać. Budowanie relacji z pracownikami naukowymi musi być oparte na profesjonalizmie, bo tylko w ten sposób możliwa będzie ocena potencjału komercyjnego prowadzonych badań i przygotowanie oferty komercyjnej uczelni [9]. Przedsiębiorca to również wymagający klient, dla którego ważny jest czas, kategorie zysku i kosztu a ewentualną współpracę z uczelnią ocenia pod względem jej wpływu na pozycję konkurencyjną przedsiębiorstwa. W obszarze kreowania popytu na badania naukowe kluczowe jest profesjonalne przygotowanie scouta do rozmowy oraz dotarcie do właściwej osoby w firmie. Dlatego budowanie relacji i utrzymywane kontaktów $\mathrm{z}$ grupami przedsiębiorstw, tj. izbami, zrzeszeniami, stowarzyszeniami oraz uczestniczenie w targach czy wystawach przemysłowych może być dla scouta bardzo pomocne.

Biorąc pod uwagę powyższe zadania scout musi charakteryzować się określonymi kompetencjami, które są bardzo podobne w obszarze podaży i popytu 
badań naukowych (Tabela 2). Działając w uczelni oraz w jej otoczeniu scout musi posiadać przede wszystkim odpowiednią wiedzę z zakresu procesu komercjalizacji. Ponieważ scouting uczelniany polega $\mathrm{w}$ dużej mierze na budowaniu relacji bardzo ważne są umiejętności komunikowania się, prezentacji publicznej oraz pracy $\mathrm{w}$ zespole. $\mathrm{W}$ zadaniach polegający na gromadzeniu informacji wymagane są umiejętności analityczne związane głównie $\mathrm{z}$ analizą jakościową, syntezą czy wyciąganiem wniosków. Obszary działania scouta mogą wymagać od niego również nieszablonowego myślenia a kontakt z nowymi rozwiązaniami i szukanie dla nich zastosowań twórczego myślenia.

Tabela 2. Kompetencje wymagane w pracy scouta.

\begin{tabular}{|c|l|}
\hline & \multicolumn{1}{|c|}{ Kompetencje } \\
\hline Kreowanie podaży badań naukowych o & Myślenie analityczne \\
potencjale komercyjnym & Komunikowanie się \\
& Kreatywność \\
& Praca w zespole \\
& Prezentacja publiczna \\
& Budowanie relacji organizacyjnych \\
\hline Kreowanie popytu na badania naukowe w & Myślenie analityczne \\
otoczeniu gospodarczym & Komunikowanie się \\
& Kreatywność \\
& Praca w zespole \\
& Prezentacja publiczna \\
& Świadomość biznesowa \\
& Budowanie relacji organizacyjnych \\
\hline
\end{tabular}

Źródło: Wiśniewska M., Głodek P., Trzmielak D. Wdrażanie scoutingu wiedzy w polskiej uczelni wyższej. Aspekty praktyczne. Łódź: Wydawnictwo Uniwersytetu Łódzkiego, 2015, p.29.

\section{Problemy do dyskusji}

Scouting uważany jest za nowoczesną metodę identyfikacji projektów naukowych, które charakteryzują się wysokim potencjałem rynkowym [10]. Jest więc narzędziem wspierającym jednostki uczelni, które tworzą system transferu wiedzy. Jednostki te najczęściej funkcjonują $\mathrm{w}$ oparciu o projekty zgłoszone przez pracowników. Pozostaje grupa naukowców, która bardziej zainteresowana jest publikacją wyników swoich badań niż ich komercjalizacją lub uważa swoje prace za mało atrakcyjne dla przemysłu, nawet w pewnej perspektywie. Dzięki scoutom możliwe będzie dotarcie również do tych pracowników naukowych, zidentyfikowanie wiedzy użytecznej w tym projektów o wysokim potencjale rynkowym na wczesnym etapie ich rozwoju i skierowanie ich np. do CTT. Dla pomyślności całego procesu komercjalizacji kluczowa jest rzetelna ocena prac naukowych, która umożliwi wersyfikację potencjału rynkowego. Według Business Incubator Innovative I3P (Inkubator I3P) przy Politechnice w Turynie scouting jest kamieniem milowym 
w procesie inkubacji. Rzetelnie wykonana praca scouta pozwala uniknąć błędów wstępnej oceny dokonywanej przez pracowników inkubatora, którzy nieraz błędnie udzielają pozytywnej oceny projektom na to nie zasługującym [11].

Proces komercjalizacji w oparciu o scouting wiedzy wymaga zaangażowania odpowiedniej liczby pracowników. Inkubator I3P proponuje tworzenie sieci scoutów w oparciu o pracowników naukowych danej uczelni, którzy posiadają wiedzę w zakresie komercjalizacji wiedzy oraz pracowników jednostek uczelnianych tworzących system transferu technologii.

Zdaniem autorki szczególną trudnością w pracy scouta jest pozyskiwanie od pracowników naukowych informacji na temat pomysłów i prowadzonych badań naukowych. Pozyskanie takich informacji będzie łatwiejsze dla scouta - pracownika danej uczelni i jednocześnie naukowca cieszącego się autorytetem i zaufaniem niż dla osoby spoza środowiska akademickiego. Trzeba również zwrócić uwagę kto jest głównym beneficjentem pracy scouta. Choć przedsiębiorstwa także czerpią korzyści z komercjalizacji wiedzy, to jednak scouting wiedzy stawia w centrum uczelnię, której dorobek ma być skomercjalizowany. Oczywiście nie można wykluczyć sytuacji, gdy pracownik naukowy nie będzie chciał współpracować z scoutem. Dotyczyć to może przypadków naukowców, którzy podjęli już z sukcesem współpracę z przedsiębiorcami

Z uwagi na szeroki zakres kompetencji działalność scoutów musi być poprzedzona odpowiednim przygotowaniem. Proces edukacji jest jednym z czterech, obok wsparcia ze strony uczelni i przedsiębiorców oraz środków finansowych, ważnych uwarunkowań powodzenia scoutingu wiedzy [12]. Wskazane byłoby, by kandydaci do roli scouta dysponowali wiedzą na temat procesu komercjalizacji. Powinni również mieć doświadczenie w tym zakresie, pojawia się pytanie: czy doświadczenie naukowe czy biznesowe? Od kandydata należy wymagać określonych predyspozycji osobowościowych, m.in. umiejętności poruszania się w świecie nauki i biznesu, wysokiego poziomu motywacji wewnętrznej, umiejętności systematycznej, samodzielnej pracy, wytrwałości, samokontroli czy otwartości na zmiany. Znalezienie kandydata spełniającego te wymogi jest bardzo trudne. Dlatego wskazane byłoby przyjęcie $\mathrm{w}$ procesie rekrutacji spełnienia minimalnej liczby wymagań. Natomiast przygotowanie do pracy scouta powinno skupiać się na poszerzeniu/uzupełnieniu pozostałych wymagań oraz uświadomieniu celów i zadań scoutingu, nabyciu umiejętności pozytywnego kształtowania wizerunku swojego i reprezentowanej uczelni, umiejętności komunikowania się, budowania relacji i twórczego myślenia $[13,12]$. Kluczowym jest więc znalezienie odpowiednich kandydatów do roli scouta. Tym bardziej, że zdaniem autorki scouci spełniają jeszcze jedną ważną rolę. W modelu uniwersytetu trzeciej generacji konieczne jest przekonanie naukowców, że muszą zmienić system wartości [14]. Scouci gromadząc informacje na temat 
potencjału komercyjnego badań realizowanych na uczelni niejako uzmysławiają naukowcom tę konieczność.

Dyskusja na temat uczelnianego scouting wiedzy toczy się również wokół następujących zagadnień: umiejscowienia zespołu scoutów w strukturze uczelni, sposobu finansowania, formy zatrudnienia, wymiaru czasu, kryteriów wyboru kandydatów, koordynacji pracy oraz metod motywacji. Ich rozstrzygnięcie powinno nastąpić wewnątrz uczelni zainteresowanych wdrożeniem scouting wiedzy.

\section{Podsumowanie}

Komercjalizacja wiedzy to dla wielu szkół wyższych wciąż nowy obszar działalności, który może przyczynić się do rozwoju i zwiększenia renomy ale może również pociągnąć za sobą negatywne konsekwencje. Budowa systemu komercjalizacji to złożony proces, uzależniony od wielu czynników tkwiących wewnątrz uczelni oraz w jej otoczeniu. Należy jednak podkreślić, że w każdej instytucji naukowej komercjalizacja zawsze zaczyna się od identyfikacji wiedzy użytecznej gospodarczo. To wymaga pozyskania informacji o zasobach uczelni, czyli tworzonej wiedzy i weryfikacji jej pod kątem możliwości współpracy z przedsiębiorstwami. Scouting jest narzędziem, który może ten etap komercjalizacji wiedzy skutecznie wspomóc, choć nie omija wszystkich barier związanych z tym obszarem działalności. W niniejszym opracowaniu jedynie zasygnalizowano kluczowe problemy związane z scoutingiem wiedzy, które stanowią przyczynek do dyskusji wokół komercjalizacji wyników badań naukowych.

\section{Bibliografia}

[1] Woźniak L. Staże narzędziem intensyfikacji wspótpracy nauki i przemystu. Wptyw wspótpracy przemystu i nauki na wzrost konkurencyjności województwa podkarpackiego. Rzeszów: Agencja Reklamowa Nowomowa, 2014.

[2] Czyżewska M., Skica T. "Współczesne modele rynków pracy naukowców na świecie jako pochodnia modeli szkolnictwa wyższego," in Kariera naukowa w Polsce. Warunki prawne, społeczne i ekonomiczne, S. Waltoś, A. Rozmus, Ed. Warszawa: Wolters Kluwer Polska, 2012, p.43.

[3] Brendzel-Skowera K. "Współpraca instytucji naukowych i przedsiębiorstw. Przypadek regionu częstochowskiego," Zeszyty Naukowe Wyższej szkoły Bankowej w Poznaniu, t. 75, nr 4, pp.121-139, 2017.

[4] Gwarda-Gruszczyńska E. "Scouting technologiczny jako instrument wspierania współpracy nauki i biznesu w regionie,” Przedsiębiorczość i Zarządzanie, t. 17, nr 2, pp. 275-286, 2016. 
[5] Rohrbeck R. "Harnessing a Network of Experts for Competitive Advantage: Technology Scouting in the ICT Industry," R\&D Management, vol. 40, No. 2, pp. 169-180, 2010.

[6] Wiśniewska M., Głodek P. "Scouting wiedzy w ramach uczelni wyższej," in Budowa potencjału uczelni wyższej do wspótprac z przedsiębiorstwami. Rola scouting wiedzy, M. Wisniewska, P. Głodek, Ed. Łódź: Wydawnictwo Uniwersytetu Łódzkiego, 2015, pp. 1124.

[7] Wiśniewska M., Głodek P., Trzmielak D. Wdrażanie scoutingu wiedzy w polskiej uczelni wyższej. Aspekty praktyczne. Łódź: Wydawnictwo Uniwersytetu Łódzkiego, 2015.

[8] Głodek P., Wieśniewska M. "Uczelniany scouting wiedzy, jako element systemu komercjalizacji wiedzy w ramach uczelni wyższej”, Ekonomiczne Problemy Ustug. Zeszyty Naukowe Uniwersytetu Szczecińskiego, No 121, pp. 279 - 292, 2015.

[9] Barski R., Cook T. Metoda identyfikacji projektów do komercjalizacji na wyższych uczelniach. Zielona Góra/Oxford: PARP, 2011.

[10] Kowalczyk I., Pawłowska J., Sarti F., Biasetti I.Z. Metody inkubacji projektów biznesowych. Warszawa: PARP, 2011.

[11] http://www.i3p.it/en/

[12] Cieślik J., Guliński J., Matusiak K.B., Sała-Późniak A. Edukacja dla przedsiębiorczości. Warszawa/Poznań: PARP, 2011.

[13] Polak B. Podstawy teorii kształcenia. Szczecin: Szczecińska Szkoła Wyższa Collegium Balticum, 2013.

[14] Wissema J.G. Uniwersytet Trzeciej Generacji. Uczelnia XXI wieku. Wrocław: Wydawnictwo Zante, 2009.

\title{
SCOUTING IN THE PROCESS OF KNOWLEDGE COMMERCIALIZATION
}

\begin{abstract}
The article is a review, its aim is to present the scouting of knowledge. This is just one of the issues related to the commercialization of knowledge, especially with the initial stage of this process. Scouting is a method of identifying scientific projects that are characterized by high market potential. The article presents the scope of scout works and their tasks and competences. Also pointed to the problems that contribute to the discussion about the commercialization of research results.
\end{abstract}

Key words: commercialization of knowledge, intellectual potential, scouting, technology transfer, university.

Data przestania publikacji do Redakcji: 31.05 .2018 Data akceptacji publikacji przez Redakcję: 05.07.2018 